\title{
Sustainable development: trends and realities of Ukraine
}

\author{
Olena Kuzmak ${ }^{1, *}$, Oleh Kuzmak ${ }^{2}$, and Borys Pohrishchuk ${ }^{3}$ \\ ${ }^{1}$ Lutsk National Technical University, Department of Finance, Banking and Insurance, 75 Lvivska st., \\ 43018 Lutsk, Ukraine \\ ${ }^{2}$ Lutsk National Technical University, Department of Marketing, 75 Lvivska st., 43018 Lutsk, \\ Ukraine \\ ${ }^{3}$ West Ukrainian National University, Vinnytsia Educational and Research Institute of Economics, \\ Department Economics, Accounting and Taxation, 37 Honty st., 21017 Vinnytsia, Ukraine
}

\begin{abstract}
The purpose of the article is to analyze the current state of the principles of sustainable development of enterprises in Ukraine, and the impact on the economy of Ukraine as a whole. To this end, was performed an analysis of Ukraine's position on the indicators of sustainable development in the dynamics. The article defines the essence of the concept of sustainable development and its main components: economic, environmental and social. The basic principles of ensuring sustainable business development are determined. The prerequisites for ensuring and supporting the implementation of the concept of sustainable development of the enterprise in management practice are considered. The proposals on the innovative nature of economic development in the context of sustainable development of domestic enterprises are studied and substantiated. It was found that the current situation in the economy of Ukraine is characterized by not very high activity of innovation, which is caused primarily by the deficiency of own funds of enterprises and limited budget funding. The ways of transition of the national economy, in particular of domestic enterprises to the model of sustainable development are suggested.
\end{abstract}

\section{Introduction}

In recent times, globalization factors are increasingly seen not as threats, but as opportunities to stimulate economic growth. Mechanisms and consequences of integration processes are especially important and topical in expanding the field and influence of intergovernmental associations. The constant intensification of economic globalization in the context of the economic crisis that has taken place not only in Ukraine but also in other countries of the European Union encourages sustainable development. In view of this, there is an urgent need to develop scientific and methodological tools for solving problems of stabilization, socio-economic reforms and restructuring of the national economy on the basis of the concept of sustainable development.

\footnotetext{
${ }^{*}$ Corresponding author: kuzmakolena3007@gmail.com
} 
The problem of sustainable development has become an important component of domestic and foreign policy of many countries on different continents. Its scientific relevance is evidenced by the attention paid to sustainable development in the scientific environment. Large-scale research is being conducted, thousands of scientific reports, fundamental monographs and textbooks, problem articles and popular brochures have been written.

Modern methods of information processing using computer technology and the latest software make it possible to significantly expand the monitoring of natural and social processes, make it more complete, efficient, and most importantly - comprehensive, and on this basis to model modern and further development of the biosphere, humanity. It should be noted an important feature of the problem of sustainable development. Its severity does not decrease over time, but on the contrary - increases.

It should be noted that the problematic issues of sustainable development have been studied in the works of domestic and foreign scientists and specialists. Despite the intensification of research efforts in these areas, the analysis of the scientific literature indicates the absence of consensus on the features, principles and factors of sustainable development of the economy as a whole, including entrepreneurial structures of sustainability, which determines the relevance of more relevant research. The purpose of the article is to study the essence, main components of sustainable development and substantiate the prerequisites for the implementation of the concept of sustainable development of the enterprise in the practice of management.

Instead, the United States adopted a resolution of the Congress "Green New Deal", which describes the plan to combat environmental change [1] and includes a broad transition to unconventional energy sources, control of greenhouse gas emissions, initiating an increase of working places in the branch of clean energy. This resolution is an initiative that increases the importance and significance of the environmental component. The new green policy is also relevant for China, where the usually rapid economic growth has caused enormous environmental damage [2]. Modern China has realized the extreme urgency of the field of environmental protection and environmental management, which has a negative impact not only on public health but also on further economic development, especially in the long-term perspective.

The European Union has adopted an EGD policy resolution, which provides for the development of an EU development strategy based on the concept of sustainable development, but lacks a detailed justification of how environmental factors will interact with social and economic factors [3].

\section{Methods}

The research methodology is based on systematic and dialectical approaches to scientific knowledge of sustainable development of industrial enterprises as an important segment of the Ukrainian economy. To achieve the goal set in the article, a set of modern research methods was used. In particular, the methods of scientific abstraction, analysis and synthesis were used in the study of the basic principles of sustainable industrial development. In the process of studying modern realities, studying the laws and contradictions of its development, empirical methods were used, namely: static observations, comparisons, statistical methods of information collection and processing and system-structural analysis. The information base of the study was the official statistics of the United Nations Development Program, the results of research by domestic and foreign scientists. 


\section{Results and Discussion}

At the end of the twentieth century, the principles of sustainable development were approved by the world community at the UN Conference on Environment and Development in Rio de Janeiro (1992) and finalized in the UN report "On Human Development" in 1994 in a universal concept sustainable development. The essence of the concept of sustainable development in its modern sense is the balance of social development in social, environmental and economic aspects. Sustainable development is development that satisfies all areas of society without compromising the capabilities of future generations [4]. Historically, Ukraine's path to sustainable development began at the same conference in Rio de Janeiro, when the Rio Declaration and the Agenda for the 21st Century Action Program were signed. Subsequently, Ukraine reaffirmed its desire to follow this path and, as a result, in 1997 the National Commission for Sustainable Development under the Cabinet of Ministers of Ukraine was established. However, in the global ranking of sustainable development indicators, Ukraine occupies not the worst, but not the best positions. Thus, in 2019, the top five in the human development index include countries such as Norway, Ireland, Switzerland, China, Iceland, (Ukraine ranks 74th out of 189 countries, which is 5 positions lower than in 2010, however, which is 12 positions higher than in 2018, and is included in the group of countries with a high level of human development) [5]. The rank is shared with Grenada, Mexico and Saint Kitts and Nevis. Between 2010 and 2019, Ukraine's HDI value increased from 0,755 to 0,779 , an increase of 2,4 percent [5]. Ukraine's 2019 HDI of 0,779 is above the average of 0,753 for countries in the high human development group and below the average of 0,791 for countries in Europe and Central Asia. [5].

According to the current Environmental Efficiency Index (EPI), in 2020 Ukraine ranks 60th among 180 countries in the world, with Ukraine excels in sustainable nitrogen management. For reference, in 2018 Ukraine ranked 109 [6], and in 2016 44th place in almost all indicators, including water quality and air purity Table 1 .

Table 1. Ukraine's position on the environmental efficiency index.

\begin{tabular}{|c|c|c|c|c|c|c|}
\hline \multirow[b]{2}{*}{ Category } & \multirow[b]{2}{*}{ Direction } & \multicolumn{2}{|c|}{2018} & \multirow[b]{2}{*}{ Direction } & \multicolumn{2}{|c|}{2020} \\
\hline & & $\begin{array}{l}\text { Place in } \\
\text { the } \\
\text { ranking }\end{array}$ & $\begin{array}{c}\text { Value } \\
(0 \rightarrow 100)\end{array}$ & & $\begin{array}{c}\text { Place in the } \\
\text { ranking }\end{array}$ & $\begin{array}{c}\text { Value } \\
(\mathbf{0} \rightarrow \mathbf{1 0 0})\end{array}$ \\
\hline Air Quality & \multirow{4}{*}{$\begin{array}{l}\text { State of the } \\
\text { environment } \\
\text { ( } 87 \text { th place in } \\
\text { the ranking; } \\
\text { value } 64,44)\end{array}$} & 105 & 64,2 & \multirow{4}{*}{$\begin{array}{l}\text { State of the } \\
\text { environment } \\
\text { (69th place in } \\
\text { the ranking; } \\
\text { value } 49,0 \text { ) }\end{array}$} & 86 & 39,8 \\
\hline $\begin{array}{c}\text { Sanitation \& } \\
\text { Drinking Water }\end{array}$ & & 63 & 60,9 & & 67 & 55,1 \\
\hline Heavy Metals & & 15 & 88,7 & & 67 & 55,1 \\
\hline Waste Management & & - & - & & 45 & 73,1 \\
\hline $\begin{array}{c}\text { Biodiversity \& } \\
\text { Habitat }\end{array}$ & \multirow{7}{*}{$\begin{array}{l}\text { Ecosystem } \\
\text { viability }(139 \text { th } \\
\text { place in the } \\
\text { ranking; value } \\
45,16)\end{array}$} & 140 & 49,1 & \multirow{7}{*}{$\begin{array}{c}\text { Ecosystem } \\
\text { viability (68th } \\
\text { place in the } \\
\text { ranking; value } \\
49,9)\end{array}$} & 139 & 37,7 \\
\hline Ecosystem Services & & 93 & 14,8 & & 109 & 30,2 \\
\hline Fisheries & & 79 & 54,3 & & 71 & 12,4 \\
\hline Climate Change & & 143 & 37,6 & & 26 & 69,2 \\
\hline Pollution Emissions & & 122 & 40,2 & & 64 & 76,6 \\
\hline Agriculture & & 17 & 57,6 & & 1 & 79,5 \\
\hline Water Resources & & 69 & 78,8 & & 60 & 14,1 \\
\hline $\begin{array}{c}\text { Environmental } \\
\text { Performance Index } \\
\text { of Ukraine }\end{array}$ & & 109 & 52,9 & & 60 & 49,5 \\
\hline
\end{tabular}


The results of the Global Competitiveness Index (GCI) 4.0 in 2019 presented at the World Economic Forum indicate that the economies of most countries are far from the "limit" of competitiveness - the aggregate ideal for all factors of competitiveness. In particular, according to the competitiveness index in 2019 Ukraine ranks 85th among 141 countries. The top five are led by Singapore, the United States, Hong Kong, the Netherlands and Switzerland [7].

In recent years, research has shown that the applied indices of human development (HDI), environmental efficiency (EPI), global competitiveness (GCI) do not fully reflect the condition and trends of social development of countries and territories. Analysis of macroeconomic indicators of any country may show the achievement of their high level, but a significant part of the population will not be "included" in the process of creating GDP, and accordingly in the distribution of public goods. The result is stratification and related problems, the main of which is poverty. Accordingly, since 2015, an integrated assessment of the Inclusive Development Index (IDI) has been carried out, according to which the capabilities of all contingents of the population are taken into account and the benefits of increased welfare in both monetary and non-monetary terms are more fairly distributed in society.

Research shows that as of 2018, Norway, Iceland, Luxembourg, Switzerland and Denmark are in the top five among countries, developed by level of inclusiveness of economic growth. Although, according to data published at the World Economic Forum (WEF) in the period from 2014 to 2018, almost a third part of the 103 countries, covered by the WEF index, experienced a decline in their inclusive development indicators, even with increasing GDP. Of the 29 countries with developed economies in the sample, all except three experienced economic growth during this period, but the majority - 16 out of 29 reported that their social integration indicators had deteriorated, according to the WEF. Income inequality has increased or remained stable in 20 of these countries with developed economies, and poverty has increased in 17.

Lithuania, Hungary, Azerbaijan, Latvia and Poland are 5 developing countries which are leading by criterion of inclusiveness of economic growth.

Ukraine belongs to the developing countries, and in 2018, according to the index of inclusive development, occupied 49th place among 74 developing countries. Ukraine's development trends indicate that during 2014-2018 the inclusiveness of its economic development decreased by $6.8 \%$. In particular, the distribution of wealth in Ukraine is one of the most uneven among all developing countries. At the same time, the level of income inequality and the level of poverty in Ukraine are low: the middle class, according to WEF experts, remains numerous, health care and support for the unemployed are at a sufficient level, and the education system promotes not bad to inclusive growth. However, the constant warfare in the east of the country contributes to regression, as it disproportionately affect the poorest groups of the population, encouraging talented people to leave the country in search of opportunities for self-realization. Priorities include improving professional education, reducing the administrative burden on setting up new enterprises, expanding funding for entrepreneurs and increasing attention to the fight against corruption $[6,7]$.

The International Chamber of Commerce has identified a number of key principles for sustainable business [6]: to recognize the priority of sustainable development as a new concept of doing business to ensure long-term success; to encourage and implement innovative business models (including to identify ways of innovative involvement of the source of financing); to recognize responsibility for the impact on the environment caused by the activities of the enterprise; to stimulate interaction with stakeholders and to contribute to the qualitative development of the staff; to introduce a new holistic approach to the production and production of a product based on the product life cycle; to ensure the 
process of value creation for the interested parties; adhere to the principles of transparency and openness; maintain ties with all parties.

Based on these principles, sustainable development of the enterprise from the standpoint of a system-integrated approach as a process of constant change, in which the use of resources, including educational components, investment, scientific and technological development, implementation of innovations, staff development and institutional change are consistent with each other and aimed at improving the efficiency of the current activities of the enterprise, satisfying its needs and achieving strategic goals in harmony with the environment [8].

The logic of such an interpretation is expressed in the comprehensive benefit for various interested internal and external stakeholders - individuals and legal entities who have a legitimate interest in the activities of the organization. Sometimes they are called groups of interests or groups of influence, which should be viewed from the position of 3 levels, in particular:

- for the regional economy - receiving budget revenues in the form of paying taxes of responsible economic entities, strengthening cooperation with government officials in other countries on the implementation of new regional development programs, solving problems with employment of local people, reducing pollution by solid industrial and household waste;

- for the national economy - the practical implementation of the concept of sustainable development, which is reflected in the reduction of negative impact on the environment, and improving the overall levels of ecological and technogenic safety in the country.

In general, the constant development of the enterprise is a complex economic category, as it combines three components or spheres of functioning, which are different [7]. In particular, the economic component - the increase of capital; social - the establishment of a social consensus between different social institutions: the company and the community, the company and the employee; ecological - rational use of natural products, reduction of anthropogenic impact of production on the environment.

However, research shows that modern enterprises face a number of problems in their activities, which stand in the way of sustainable development and which can be grouped by social, economic and ecologic groups.

The economic problems of the development of modern industrial enterprises can be attributed to: imbalance in the structure of enterprises; high level of wear and tear of fixed assets; insufficient adaptation of the organizational structure to the current market conditions; dissatisfaction with the needs of intersectoral cooperation; low rates of technological renewal of productions; destruction of the system of reproduction of production potential, high-tech productions; growth of dependence of activity of enterprises on the foreign market, etc.

The social component of the sustainable development of the enterprise is aimed at improving the living conditions of the population, preserving the stability of social and cultural systems in which it is located. Based on the results of the research, the following social problems of the sustainable development of modern industrial enterprises can be identified: loss of qualified staff; problems of creation of working places; low value of the workforce; low level of social expenditures; reduction of the incentive field of wages; the inadequacy of the youth career guidance system for the needs of the labor market; low level of investment in social infrastructure facilities, etc.

The results of economic and social development of the enterprise should be evaluated taking into account the ecological consequences. It should be noted that the environmental safety of enterprises is largely determined by their technical and technological reequipment, which contributes to the reduction of the pollution of environment. Unfortunately, in modern economic conditions, instability of the political and economic 
situation, imperfection of legislation, corruption of the government, a sense of permissiveness, lead to the fact that the management of Ukrainian enterprises due to impossibility, and often unwillingness to invest in new technologies, thirst for economic enrichment, extremely little attention is paid to environmental factors of sustainable development.

Among the ecological problems of development of modern industrial enterprises, the following can be distinguished: ecological imperfection of technologies; non-rational use of natural products; low level of ecological safety of foreign innovations (realization in Ukraine of ecologically polluting technologies), etc. In particular, it is very common to ignore compliance with the requirements in terms of the use of technology to reduce harmful emissions into the atmosphere, proper sanitation, solid waste disposal, etc. In addition, Ukraine still preserves and uses energy-intensive production technologies. In comparison with the developed countries of Western Europe, the number of energy producers in Ukraine is 8-10 times higher per unit of production.

In Ukraine, the issue of achieving sustainable development of the enterprise, in many cases, is limited to taking into account mainly only two of its components - economic and social, levelling at the same time the third field - ecological. The problem of environmental protection and rational use of nature is considered on a macro level and is more and more theoretical, despite the adoption of the Strategy of National Environmental Policy of Ukraine for the period up to 2020. Meanwhile, at domestic enterprises, at present there is no effective system of ecological management. This indicates that companies are not ready to solve urgent ecological problems based on European standards, as in domestic practice there is no clear mechanism for the practical implementation of European environmental policy.

Based on this, the study of the experience of EU countries in the development and implementation of environmental policy will be extremely useful for Ukraine, as it will facilitate the use of methodology, tools and mechanisms for adaptation in practice of Ukraine, which has failed a strategic course for European integration. At the same time, the goal of sustainable development should ensure the integration of efforts regarding economic growth, the pursuit of social justice and rational use of nature. In the process of defining the goals of sustainable development, the corresponding tasks and indicators for the future, it is necessary to store the global development options, principles of sustainable development and public opinion on the vision of future development.

In addition, research shows that the purpose of sustainable development of the national economy, including modern enterprises is to ensure competitiveness, independence and security, increase profitability through the development of high-tech industries, which in turn is not possible without increasing innovation in various sectors of the economy. That is, the innovative character of economic development in the context of sustainable development is becoming more and more the foundation that defines economic strength. It is safe to say that both entrepreneurs and consumers and the state are interested in intensifying innovation, as it provides production and access to new and competitive types of goods that provide a guaranteed profit, accumulation of free capital and the possibility of investing in expanding production, increasing revenues to the budgets of all levels, inflows of foreign capital.

Innovation in this context is seen not as an end in itself, but as a tool stimulating growth and development. The concept of "sustainable development" addresses this issue of additional importance: if growth should be provided for a long period of time, then growth policy must pay sufficient attention to the factors that constrain growth: the environment, depletion of raw materials, energy, people, etc.

The current situation in the economy of Ukraine is characterized by not very high innovation activity, which is primarily due to the lack of own funds of enterprises and 
limited budget funding. Thus, according to the global innovation rating Global Innovation Index 2020, Ukraine ranked 45rd among 131 countries, being between Thailand (44nd place) and Romania (46th place) $[9,10,11]$. Although compared to previous years, Ukraine has slightly improved its results (for comparison, in 2019 - 47, in 2018 - 43th place, respectively). In addition, statistics show a low innovative activity of industrial enterprises in Ukraine, compared to developed countries, especially the EU countries. In Ukraine, the share of enterprises engaged in innovation does not exceed 19\% in 2016-2019, and in 2019 the number of innovative enterprises decreased from 18,9 to $16,4 \%$, while the number of innovatively active enterprises in the EU is from 40 and even up to $70 \%$ of their total number [12].

It should be noted that the effective development of innovation at the enterprise level is impossible without increasing the scale of state regulation and applying the experience of developed European countries in the implementation of innovative models of economic development. That is, there should be a set of measures covering all directions of innovations. However, it is necessary to understand and take into account the peculiarities of innovation policy of leading countries and developing countries. In particular, in countries with a low level of economic development (including Ukraine), business entities are trying to strengthen their potential and competence. Accordingly, the situation in economic relations often characterized by minor competition in commodity markets; large enterprises as a rule take the lead in the modernization process and often have close links with financial institutions, besides it is easy for such enterprises to use government subsidies to support their development; the inflexible labor market prefers the accumulation of experience within firms, rather than maintaining mobility between firms; little attention is paid to the development of quality education and as a consequence the formation of highly qualified personnel. In the leading countries, the opposite is happening: more attention is paid to radical innovation, strong competition in the markets for goods and services and the education system, which prefers the acquisition of broad basic knowledge and higher education. That is, as we see, it is necessary to apply a policy that encompasses science, education and innovation (this approach is called "process policy" in the European Union) and is critical to realizing the potential for economic growth, as these policy areas mutually reinforce each other. If they do not coordinate well enough, they can create obstacles that will limit growth.

Thus, sustainable development that based on innovation growth policy is an objective and managed process, in which the main role should be played by the state, which has guarantee security in the political, economic, social, defence and environmental spheres. In addition, growth and innovation policies by their nature should be horizontal, that is address all areas that affect innovation, but be coordinated; it is necessary to pay more attention to the system approach and network characteristics of innovative systems. Ignoring this issue will lead to the loss of important components of sustainable growth policy based on innovation; Innovation policy must be commensurate with the level of development of the national economy and take into account its specifics, as unreasonable copying of successful policies of other countries is likely to lead to inefficient use of resources.

\section{Conclusion}

In general, in order to transition the national economy, in particular domestic enterprises to the model of sustainable development, it is necessary to comply with the following conditions:

- environmentally friendly development of production (economy), the result of which should be the achievement of a higher level of welfare while solving resourceenvironmental and social tasks; 
- reproduction and rational use of all types of resources, introduction of an effective system of nature management and environmental protection, maintenance of ecological balance as a basis for preserving the environment for present and future generations;

- the need for systematic ecological and economic restructuring of industry, agriculture, coordination of goals and measures for the development of industries and regions, individual enterprises, which are elements of the socio-ecological economic system of the country;

- cooperation with international organizations on issues of sustainable development and solving resource and solution of resource-ecological problems based on innovative development of economic, introduction of the best experience and advanced scientifictechnical and socio-economic achievements into the practice of management;

- approval in society of the principles of social justice, overcoming social problems and stabilization on this basis of the demographic situation in the country, reducing morbidity and increasing life expectancy.

Today and in the long run, the model of inclusive growth in Ukraine should be based on European experience and follow the principles of intellectual, sustainable and comprehensive development. If we turn to history, the remark of Stefan Fule at the meeting of the EU-Ukraine Parliamentary Cooperation Committee held in Brussels on March 22-23, 2010 that Ukraine now needs "concrete reforms rather than just encouraging words" is still relevant today.

In our opinion, the general perspective strategy of building and development of human potential in Ukraine should be formed, based on the development strategy - "Europe 2020" in the center of which is a person. In particular, these are three laconic priorities: smart development (development of the economy based on knowledge and innovation); sustainable development (more efficient use of resources, environmental protection); socially-oriented growth (economic development that promotes social and territorial cohesion, employment growth, social harmonization).

Regarding intellectual development in Ukraine, it should affect the field of education with a focus on innovations, related to health and the environment. Priorities for education include creating favorable conditions for the younger generation to enter professional life, especially for finding their first job, including by using the launch of general monitoring of vacancies. Achieving of sustainable growth must be ensured through measures to improve energy efficiency, building a "low-carbon" economy. The big task is standing in front of industrial policy, which must maintain both high competitiveness of the industry and serve the goals of sustainable development. In addition, inclusive growth should be in the area of advanced training and retraining of employees in order to create conditions for more full employment and professional development, adequate to the requirements of the modern labor market, including in new sectors of the economy.

Unfortunately, Ukraine is only taking the first steps towards the full implementation of strategic planning at all levels of government. However, it should be noted that today work is underway on the state development strategy "Ukraine-2030" and this document, if it will be approved, promises to be profound and detailed.

\section{References}

1. Friedman, L. (2019). What is the Green New Deal? A climate proposal, explained. The New York Times.

2. Li, X. (2014). Scientific development and a new green deal. China Finance and Economic Review, 2, 2, 8. https://doi.org/10.1186/2196-5633-2-2 
3. Matvieieva, Y., Myroshnychenko, I., \& Valenkevych, L. (2019). Optmization model of the socio-ecological-economic development of the administrative territory. Journal of Environmental Management and Tourism, 10(8), 1874-1899.

4. Rio De Janeiro Declaration on Environment and Development. (1992). Planet Earth Summit. Rio de Janeiro. https://zakon.rada.gov.ua/cgibin/laws/main.cgi?nreg=995 455\#Text

5. Human Development Report. (2020). http://hdr.undp.org/en/2020-report

6. Wendling, Z.A., Emerson, J.W., Esty, D.C., Levy, M.A., de Sherbinin, A., \& et al. (2018). Environmental Performance Index. New Haven, CT: Yale Center for Environmental Law \& Policy. https://epi.yale.edu/downloads/epi2018reportv06191901.pdf

7. World Economic Forum. (2021). Global Competitiveness Report (2010-2020). https://www.weforum.org/reports

8. International Chamber of Commerce. (2015). Business Chapter for Sustainable Development - Business Contributions to the UN Sustainable Development Goals. Document no. 213/18-13. https://iccwbo.org

9. Cornell University, INSEAD, and WIPO. (2018). The Global Innovation Index 2018: Energizing the World with Innovation. Ithaca, Fontainebleau, and Geneva. https://www.wipo.int/edocs/pubdocs/en/wipo_pub_gii 2018-intro5.pdf

10. Cornell University, INSEAD, and WIPO. (2019). The Global Innovation Index 2019: Creating Healthy Lives.The Future of Medical Innovation. Ithaca, Fontainebleau, and Geneva. https://www.globalinnovationindex.org/userfiles/file/reportpdf/gii-full-report2019.pdf

11. Cornell University, INSEAD, and WIPO. (2020). The Global Innovation Index 2020: Who Will Finance Innovation? Ithaca, Fontainebleau, and Geneva. https://www.wipo.int/edocs/pubdocs/en/wipo_pub_gii_2020.pdf

12. State Statistics Committee of Ukraine. (2019). Scientific and Innovative Activity in Ukraine in $2018 \mathrm{Kiev}$, Ukraine. http://www.ukrstat.gov.ua 